\title{
Polyploidy in a natural population of mussel, Mytilus trossulus
}

\author{
A. González-Tizón ${ }^{\mathrm{a}}$, A. Martínez-Lage ${ }^{\mathrm{a}}, \mathrm{J}$ Ausio $^{\mathrm{b}}$, and J. Méndez ${ }^{\mathrm{a}^{*}}$ \\ ${ }^{\text {a }}$ Departamento de Biología Celular y Molecular, Facultad de Ciencias, La Zapateira, 15071 La Coruña, Spain. \\ ${ }^{\mathrm{b}}$ Department of Biochemistry and Microbiology, University of Victoria, Victoria, BC V8W 3P6, Canada.
}

Genome, volume 43, issue 2, pages 409-411, march 2000

Received 25 may 1999, accepted 10 december 1999

\section{How to cite:}

González-Tizón, A., Martínez-Lage, A., Ausio, J., \& Méndez, J. (2000). Polyploidy in a natural population of mussel, Mytilus trossulus. Genome, 43(2), 409-411. https://doi.org/10.1139/g99-138

\begin{abstract}
We have analyzed natural polyploidy in a population of Mytilus trossulus from Vancouver Island (British Columbia, Canada) by means of cytogenetic techniques. Results obtained are the first reporting on this type of numerical chromosome aberrations in mussels.
\end{abstract}

Keywords: mussel; Mytilus trossulus: polyploidy; chromosome.

The study and detection of natural polyploidy is very scarce in bivalve molluscs. Among the few references about this topic we have found the description of this process indifferent species belonging to genus Lasaea (Thiriot-Quiévreux et al. 1989; O Foighil and Thiriot-Quiévreux1991) and in a neoplastic process developed in the clam Macoma balthica (Thiriot-Quiévreux and Wolowicz 1996). Elston et al. (1990) related an increase of nuclear DNA content in the mussel Mytilus trossulus affected of a neoplasia, too.

In this study, we observed a case of natural polyploidy in the mussel, M. trossulus. Samples were collected from Esquimalt Lagoon, Vancouver Island (British Columbia, Canada) during the summers of 1995 and 1996. Once in the laboratory, animals were fed with Isochrisis sp. microalgae for ten days and, then, treated for metaphase obtention according to Méndez et al. (1990). This species shows a diploid karyotype $2 n=28$, constituted by seven metacentric and seven submetacentric chromosome pairs (Fig. 1). In 4 of 168 individuals analyzed, we have detected polyploid metaphases showing a high chromosome number (Fig. 2), which varied from 48 to 92 . The modal number showed a value between 74 and 78 chromosomes (Table 1), and it was not the same in each one of the polyploid mussels.

Polyploid metaphases, obtained from gill tissue, showed 1 to 3 large metacentric and 6 large submetacentric chromosomes, a variable number of medium-sized chromosomes (which were characterized according to the centromere position) and small-sized chromosomes whose centromeres were very difficult to visualize. However, in each one of the polyploid cells analyzed, we observed that metaphases always showed the 6 large submetacentric chromosomes (Fig. 2). 


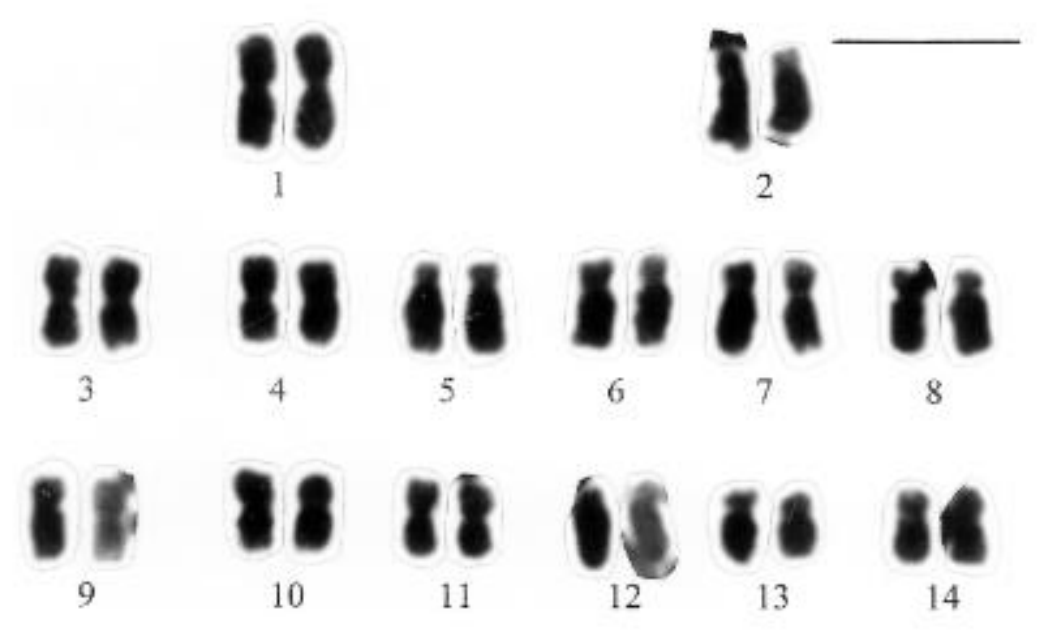

Figure 1. Karyotype of Mytilus trossulus showing the seven metacentric $(1,3,4,9,10,11,14)$ and the seven submetacentric chromosome pairs $(2,5,6,7,8,12,13) \cdot$ Bar $=5 \mu \mathrm{m}$

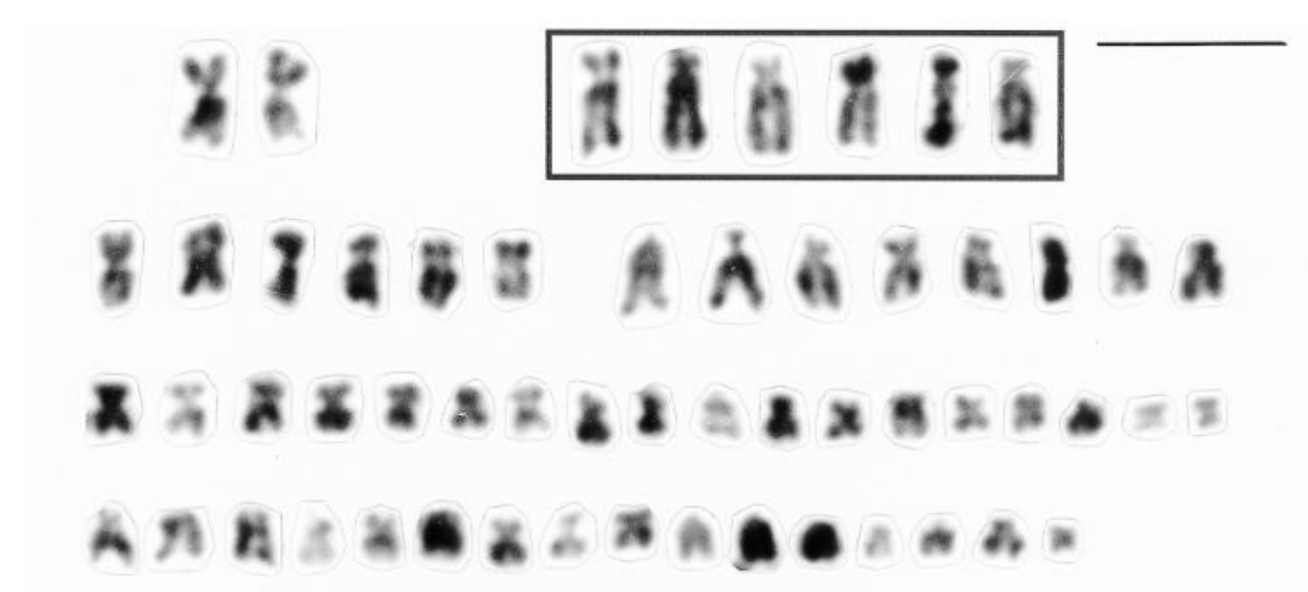

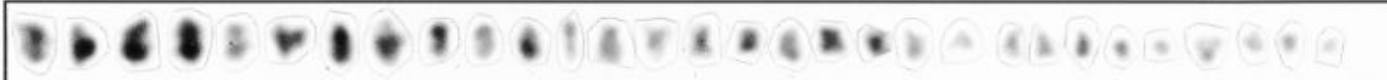

Figure 2. Karyotype of a polyploid cell showing 86 chromosomes. First line, 2 large metacentric and, (in square) the six large submetacentric chromosomes. Second line, 6 medium metacentric and 8 medium submetacentric chromosomes. Third line, 18 medium metacentric chromosomes. Fourth line, 16 medium submetacentric-subtelocentric chromosomes. Fifth line, the small-sized chromosomes whose centromeres were difficult to visualize. Bar $=5 \mu \mathrm{m}$

The six larger submetacentric chromosomes that appeared in every one of the polyploid metaphases analyzed could suggest that multiple cell replications have taken place. We suppose that along this process, chromosome pair No. 2 is involved, because the morphology and size of this chromosome pair are similar to the morphology and size of the six larger submetacentric ones. In this sense, Moore et al. (1991), analyzing a systemic neoplasia in Mytilus sp. mussels, detected the existence of two cellular forms whose DNA contents showed the presence of tetraploid and pentaploid levels. However, in our results these cells appear to be hexaploid.

On the other hand, the proportion of polyploid cells in the 4 affected mussels was different from one individual to another (Table 2); in the other 164 mussels, we did not observe polyploid cells. Thus, whereas 
two of the samples showed a proportion of polyploid cells higher than $95 \%$, in the other two it was close to $10 \%$. Furthermore, the mitotic index of unaffected individuals reached maximum values of $0.11 \%$, while the mitotic index of individuals with polyploid metaphases was $0.37 \%$, an increase three times above the normal.

Table 1. Number of metaphases with high number of chromosomes.

\begin{tabular}{|c|c|c|c|c|c|c|}
\hline \multirow[b]{2}{*}{ No. chromosomes } & \multicolumn{5}{|c|}{ Mussel } & \multirow[b]{2}{*}{ Total } \\
\hline & 1 & 2 & 3 & & 4 & \\
\hline$<64$ & 2 & & - & 1 & - & 3 \\
\hline $64-68$ & 7 & & 1 & 8 & - & 16 \\
\hline $69-73$ & 12 & & 2 & 8 & 1 & 23 \\
\hline $74-78$ & 7 & & 1 & 17 & 2 & 27 \\
\hline $79-83$ & 8 & & 1 & 12 & - & 21 \\
\hline$>84$ & 2 & & - & 4 & - & 6 \\
\hline
\end{tabular}

Table 2. Proportion of polyploid and healthy cells, and total numbers of cells analzyed.

\begin{tabular}{lrrr}
\hline Mussel & \% of polyploid cells & \% of healthy cells & Total \\
\hline 1 & 96.67 & 3.33 & 150 \\
2 & 11.11 & 88.89 & 63 \\
3 & 95.22 & 4.78 & 586 \\
4 & 9.38 & 90.62 & 32 \\
\hline
\end{tabular}

Along the coasts of British Columbia, blue mussel species frequently develop an illness known as "The Summer Mortality Syndrome" (Bower 1989; Bower et al. 1994). Population monitoring and histological studies allowed us to identify and diagnose it as a haemocytic neoplasia. As pointed out by Elston et al. (1988), the neoplastic hemocytes appear in circulation and rapidly replace the healthy hemocytes, altering the normal physiological processes. The neoplasia is progressive and can be transmitted by cohabitation. Such characteristics could explain the high mortality in these molluscs during the summer months. In this geographic area, mortality can exceed $75 \%$ of mussels. Perhaps polyploidy described in this work could be the consequence of a neoplastic process, and it is the first time that it is described in mussel by cytogenetic methodology and chromosome analysis. Further studies must be carried out to investigate if this neoplasia is caused by an infectious agent (virus) or by environmental pollution (Brown et al. 1979; Oprandy et al. 1981; Reinisch et al. 1984). Recently, Krishnakumar et al. (1999) did not find evidence that chemical contaminants induce the development of such a process.

\section{Acknowledgements}

We are very grateful to Dr. J.L. Littlepage from the Biology Department (University of Victoria) for providing us with the microalgae suspensions used to feed the mussels, and to Jason Bell for carefully reading the manuscript. This work has been supported by Natural Sciences and Engineering Research Council of Canada (NSERC) grant OGP0046399, Xunta de Galicia (XUGA) grants $10303 B 93$ and10306B95 (Spain). 


\section{References}

Bower, S.M. 1989. The summer mortality syndrome and haemocytic neoplasia in blue mussels (Mytilus edulis) from British Columbia. Can. Tech. Rep. Fish. Aquat. Sci. 1703.

Bower, S.M., McGladdery, S.E., and Price, I.M. 1994. Synopsis of infectious diseases and parasites of commercially exploited shellfish. Annu. Rev. Fish Dis. 4: 1-199.

Brown, R.S., Wolke, R.E., Brown, C.W., and Saila, S.B. 1979. Hydrocarbon pollution and the prevalence of neoplasia in New England soft shell clams. In Animals as monitors of Environmental Pollutants. Natl. Acad. Sci., Washington, D.C. pp. 41-50.

Elston, R.A., Kent, M.L., and Drum, A.S. 1988. Transmission of hemic neoplasia in the bay mussel, Mytilus edulis, using whole cells and cell homogenate. Dev. Comp. Immunol.12: 719-722.

Elston, R.A., Drum, A.S., and Allen, S.K. Jr. 1990. Progressive development of circulating polyploid cells in Mytilus with hemic neoplasia. Dis. Aquat. Org. 8: 51-59.

Krishnakumar, P.K., Casillas, E., Snider, R.G., Kagley, A.N., and Varanasi, U. 1999. Environmental contaminants and the prevalence of hemic neoplasia (Leukemia) in the common mussel (Mytilus edulis Complex) from Puget Sound, Washington,U.S.A. J. Invertebr. Pathol.73: 135-146.

Méndez, J., Pasantes, J.J., and Martínez-Expósito, M.J. 1990. Banding patern of mussel (Mytilus galloprovincialis) chromosomes induced by 2XSSC / Giemsa-stain treatment. Mar. Biol. (Berlin), 106: 375-377.

Moore, J.D., Elston, R.A., Drum, A.S., and Wilkinson, M.T. 1991. Alternate pathogenesis of systematic neoplasia in the bivalve mollusc Mytilus. J. Invertebr. Pathol. 58: 231-243.

O Foighil, D. and Thiriot-Quiévreux, C. 1991. Ploidy and pronuclear interaction in Northeastern Pacific Lasaea Clones (Mollusca: Bivalvia). Biol. Bull.181: 222-231.

Oprandy, J.J., Chang, P.W., Provovost, A.D., Cooper, D.R., Brown,R.S., and Yates, V.J. 1981. Isolation of a viral agent causing hematopoietic neoplasia in the soft-shell clam, Mya arenaria. J. Invertebr. Pathol. 38: 45-51.

Reinisch, C.L., Charles, A.M., and Stone, A. 1984. Epizootic neoplasia in shoft shell clams colected from New Bedford Harbor, Hazard. Waste, 1: 73-81.

Thiriot-Quiévreux, C. Insua, A. and Albert, P. 1989. Poliploidie chez un bivalve incubant, Lasaea rubra (Montagu). Comptes Rendus de l'Academie des Sciences Paris, 308: 115-120.

Thiriot-Quiévreux, C. and Wolowicz. M. 1996. Étude cayologique d'une néoplasie branchiale chez Macoma balthica (Mollusca, Bivalvia). Comptes Rendus de l'Academie des Sciences Paris, 319: $887-892$.

\footnotetext{
*fina@udc.es
} 